\title{
Profile and artificial insemination practices of technicians and the artificial insemination success rates in Leyte, Samar, and Biliran, Philippines (2011-2015)
}

\author{
Adrian P. Ybañez ${ }^{1,2}$, Rochelle Haidee D. Ybañez ${ }^{1}$, Maxine O. Caindec ${ }^{1}$, Louie V. Mani ${ }^{1}$, Julius V. Abela ${ }^{3}$, \\ Edgar S. Nuñez ${ }^{3}$, Johnson T. Royo Jr $r^{3}$ and Ivy Fe M. Lopez ${ }^{3}$
}

\begin{abstract}
1. Department of Biology and Environmental Science, College of Science, University of the Philippines Cebu, Lahug, Cebu City 6000, Philippines; 2. Department of Research, Gullas College of Medicine, University of the Visayas, Banilad, Mandaue City 6014, Cebu, Philippines; 3. Philippine Carabao Center at Visayas State University, Visca, Baybay City 6521-A, Leyte, Philippines.

Corresponding author: Adrian P. Ybañez, e-mail: dr.adrianpybanez@gmail.com,

Co-authors: RHDY: rochelledybanez@gmail.com, MOC: mocaindec@gmail.com, LVM: manilouie@gmail.com, JVA: docjulsgrebitabela@gmail.com, ESN: edgarnunezpccvsu@gmail.com,

JTR: johnsonpccvsu95@gmail.com, IFML: ivy_fe_lopez@yahoo.com

Received: 14-08-2016, Accepted: 17-01-2017, Published online: 13-02-2017
\end{abstract}

doi: 10.14202/vetworld.2017.181-186 How to cite this article: Ybañez AP, Ybañez RHD, Caindec MO, Mani LV, Abela JV, Nuñez ES, Royo JT, Lopez IFM (2017) Profile and artificial insemination practices of technicians and the artificial insemination success rates in Leyte, Samar, and Biliran, Philippines (2011-2015), Veterinary World, 10(2): 181-186.

\begin{abstract}
Background: Artificial insemination (AI) is a reproductive biotechnology that may be influenced by several factors, including the profile of the technicians and the practices used. Assessing technician's profile and their AI practices can be significant in improving AI success rate.
\end{abstract}

\begin{abstract}
Aim: This study aimed to know the profile and current practices used by AI technicians (AITs), to determine the success rates of AI in water buffaloes in Leyte, Samar, and Biliran from 2011 to 2015, and to evaluate the possible association between the parameters investigated.
\end{abstract}

Materials and Methods: A total of 50 AITs from Leyte, Samar and Biliran, Philippines, were interviewed using a fixed questionnaire about their profile and employed AI practices, and 20,455 AI-related records of the Philippine Carabao Center (PCC) at Visayas State University (VSU), Baybay City, Leyte, were screened and analyzed. AI success rates were determined by retrospective analysis of the gathered data. Statistical analysis was performed between the technician profile and practices and the AI success rates.

Results: Results revealed that most of the technicians were male, around 31-40 years old, married, college graduates, working under local government units, had other sources of income, and with 1-5 years of continuous AI practice averaging 51-100 inseminations per year. Most of them attended only one basic training seminar, which was conducted more than 3 years ago in PCC in VSU. AI success rates were recorded highest in 2011 and lowest in 2015. Statistical analyses showed that some technician profile parameters (civil status, average AI per year, and the training center) and several practices (checking of soft cervix, rectal palpation, thawing temperature method, straw cutting method, and semen deposition) might have an influence on the success of AI.

Conclusion: This study documents the first report on AIT's profile and their employed AI practices and the AI success rates in Leyte, Samar, and Biliran, Philippines. Selected profile parameters and AI practices may influence AI success rates. AITs should perform more AI services and revisit the employed practices.

Keywords: artificial insemination, artificial insemination technician, Philippines, profile, water buffalo.

\section{Introduction}

Artificial insemination (AI) is among the most effective breeding methods that afford widespread propagation of genes carried by superior males [1]. It is more profitable than the natural service method [2]. The success of AI depends on several factors, including the technician and practices employed $[3,4]$. Assessing technician's profile and

Copyright: Ybañez, et al. Open Access. This article is distributed under the terms of the Creative Commons Attribution 4.0 International License (http://creativecommons.org/licenses/ by/4.0/), which permits unrestricted use, distribution, and reproduction in any medium, provided you give appropriate credit to the original author(s) and the source, provide a link to the Creative Commons license, and indicate if changes were made. The Creative Commons Public Domain Dedication waiver (http:// creativecommons.org/publicdomain/zero/1.0/) applies to the data made available in this article, unless otherwise stated. their AI practices can be significant in improving AI success rate.

In the Philippines, the use of AI for livestock started on the establishment of the Philippine Carabao Center (PCC) in 1993 [5]. Water buffaloes (Bubalus bubalis) are considered integral to the Philippine agricultural industry. Although these animals are mostly used for draft, its utilization as a food source may have increased, which may have contributed to its population decline. According to the Philippine Bureau of Agricultural Statistics, the total buffalo population in 2004 was 3.28 million, which decreased to 2.96 million in 2011. Despite the Carabao Development Program of PCC [6], the water buffalo population has been declining. In Eastern Visayas Region (EVR), Typhoon Haiyan may have also contributed 
to its reduction. Recent reports indicated that EVR accounted for $9.7 \%$ of the total water buffalo population in the country. To help improve the declining water buffalo population, AI has been practiced in the region. However, on a national scale, the success rates are considered low [7].

While studies on AI appear to be well reported in other countries, reports and studies in the Philippines remain limited or are unpublished and are usually difficult to access. Environment and management $[8,9]$, which have been shown to affect AI, may differ depending on the location, economic condition, and culture. Studying the profile of technicians and practices employed and the success of AI in a selected area will be beneficial not only to the Philippines but also to other countries having similar conditions. Hence, this study was conducted.

\section{Materials and Methods}

\section{Ethical approval}

The study was conducted in accordance with the principles of Helsinki declaration developed by the World Medical Association. Informed consent was obtained from the respondents. No live animal was used in this study.

\section{Study design, selection of respondents and study area}

This study utilized a descriptive-analytical design and was conducted in five areas from the VSU, Philippines (Leyte, Southern Leyte, Biliran, Western Samar and Northern Samar) from March to May 2016. Out of the 250 AI technicians (AITs) (regardless of sex, status, educational attainment, employment, and age) contacted, only 50 were able to complete the questionnaires.

\section{Survey questionnaire and AI records}

The pre-tested, researcher-made, fixed questionnaire composed of two parts. The first part covered the profile of the AITs, including age, sex, civil status, educational attainment, AI training, nature of job assignment, receipt of service fees, other sources of income, nature of income sources, number of years as AIT, average number of AI per year, number of AI trainings attended, level of training attended, place of training, and last AI training attended. The second part included the practices employed. AI success rates (calf drop and the number of animals provided with AI services) were determined based on the available records at the PCC in Visayas State University (VSU), Baybay City, Leyte. A total of 20,455 records were screened: 2011 (2993), 2012 (4120), 2013 (4857), 2014 (4645), and 2015 (3840).

\section{Data processing and statistical analysis}

Data gathered from the questionnaires and AI records were manually tabulated and encoded in Microsoft Excel Office using appropriate variable coding. Encoded data were then imported into statistical software for analysis. Descriptive statistics was employed. Significant differences between technician profile factors and AI success rates were analyzed using one-way ANOVA and independent t-tests.

\section{Results and Discussion \\ AIT profile}

Information on profile revealed that most AITs were from Northern Leyte (42\%), male (92\%), $31-40$ years old (36\%), and married (78\%) (Table-1). These findings were similar to the study of Russi et al. [10] where most AITs were also college graduates (58\%). Singh and Nanda [11] showed that higher success rates were found in professional degree holders than diploma holders. 30 technicians were working under local government units (LGUs). The majority of the technicians did not receive fees for the AI services rendered since they had other sources of income. The initiative of PCC in 2006 to train farmers to work as village-based AITs was evident with $38 \%$ of the technicians being land farmers also. These technician farmers did not receive fees for their services as they were closely associated with their community, implying that interpersonal relationships were more important than receiving remuneration.

The majority of technicians had 1-5 years of continuous AI practice, with an average number of 51-100 inseminations per year. Several studies have shown that experienced technicians can have higher success rates than new technicians [12]. Most technicians had attended only one basic training seminar, conducted more than 3 years ago. Akhtar et al. [13] and Boettcher and Perera [14] showed that higher success rates were associated with technicians who attended refresher courses. Majority attended their training at PCC in VSU, probably because this is the training center closest to Leyte, Samar, and Biliran. On the other hand, the number of AI technicians after 10 years of AI practice declined. This may be due in part of the reassignments in the LGU, retirement or shift of career path.

\section{AI practices}

All AITs checked heat before performing AI. Heat was confirmed mostly (92\%) through the appearance of clear mucus discharges. The majority $(90 \%)$ of the AITs checked the time of heat before insemination. Time of response of $70 \%$ of AITs was within $12 \mathrm{~h}$ after they are informed of the status of the animal. Most (84\%) AITs used a thermometer to check the thawing temperature of semen. All the AITs checked thawing time. However, only $22 \%$ used a watch to do this and $76 \%$ used manual $/$ mental counting. A thawing time of $1-10 \mathrm{~s}$ was practiced by $56 \%$ of the AITs. Either cutter $(54 \%)$ or scissors $(58 \%)$ was used to cut the straw, with about $76 \%$ of the AITs cutting the straws straight. Almost all (98\%) used gloves and 52\% did not reuse them. The majority (66\%) used soap as a lubricant, but there were still 16\% that did not use any. AITs deposited the semen in the body of the uterus (86\%) and the mid-cervix if the standard time of AI has lapsed 
Table-1: Profile of AITs in Eastern Visayas $(n=50)$.

\begin{tabular}{|c|c|}
\hline Parameter & n (\%) \\
\hline \multicolumn{2}{|l|}{ Location } \\
\hline Leyte & $21(42.0)$ \\
\hline Southern Leyte & $15(30.0)$ \\
\hline Biliran & $2(4.0)$ \\
\hline Western Samar & $6(12.0)$ \\
\hline Northern Samar & $6(12.0)$ \\
\hline \multicolumn{2}{|l|}{ Sex } \\
\hline Male & $46(92.0)$ \\
\hline Female & $4(8.0)$ \\
\hline \multicolumn{2}{|l|}{ Age } \\
\hline $18-30$ & $7(14.0)$ \\
\hline $31-40$ & $18(36.0)$ \\
\hline $41-50$ & $16(32.0)$ \\
\hline Above 50 & $9(18.0)$ \\
\hline Range: $23-62$, Mean: 40.8 & \\
\hline \multicolumn{2}{|l|}{ Civil status } \\
\hline Single & $7(14.0)$ \\
\hline Married & $39(78.0)$ \\
\hline Widowed & $1(2.0)$ \\
\hline Prefer not to say & $3(6.0)$ \\
\hline \multicolumn{2}{|c|}{ Highest educational attainment } \\
\hline Elementary graduate & $1(2.0)$ \\
\hline High school level & $6(12.0)$ \\
\hline High school graduate & $6(12.0)$ \\
\hline College level & $7(14.0)$ \\
\hline College graduate & $29(58.0)$ \\
\hline Post-graduate & $1(2.0)$ \\
\hline \multicolumn{2}{|l|}{ Nature of job assignment } \\
\hline LGU & $30(60.0)$ \\
\hline Community/village based & $15(30.0)$ \\
\hline Prefer not to say & $5(10.0)$ \\
\hline \multicolumn{2}{|l|}{ Receipt of service fees } \\
\hline Not at all & $26(52.0)$ \\
\hline Always & $9(18.0)$ \\
\hline Sometimes & $12(24.0)$ \\
\hline Prefer not to say & $3(6.0)$ \\
\hline \multicolumn{2}{|l|}{ Others source of income } \\
\hline No & $10(20.0)$ \\
\hline Yes & $34(68.0)$ \\
\hline Prefer not to say & $6(12.0)$ \\
\hline \multicolumn{2}{|c|}{ Nature of other income sources } \\
\hline Land farming & $19(38.0)$ \\
\hline Fishing & $3(6.0)$ \\
\hline Animal raising & $16(32.0)$ \\
\hline Others & $3(6.0)$ \\
\hline \multicolumn{2}{|l|}{ Number of years as AIT } \\
\hline$<1$ & $3(6.0)$ \\
\hline $1-5$ & $26(52.0)$ \\
\hline $6-10$ & $10(20.0)$ \\
\hline Above 10 & $8(16.0)$ \\
\hline Prefer not to say & $3(6.0)$ \\
\hline $\begin{array}{l}\text { Range: } 1 \text { month-18 years } \\
\text { SD: } 4.6\end{array}$ & \\
\hline \multicolumn{2}{|l|}{ Type of AI practice } \\
\hline Continuous & $43(86.0)$ \\
\hline Discontinuous & $5(10.0)$ \\
\hline Prefer not to say & $2(4.0)$ \\
\hline \multicolumn{2}{|l|}{ Average AI per year } \\
\hline $10-50$ & $18(36.0)$ \\
\hline $51-100$ & $20(40.0)$ \\
\hline Above 100 & $5(10.0)$ \\
\hline Prefer not to say & $3(6.0)$ \\
\hline Range: $10-250$, Mean: 70 & \\
\hline \multicolumn{2}{|c|}{ Number of AI trainings attended } \\
\hline 1 & $30(60.0)$ \\
\hline 2 & $12(24.0)$ \\
\hline More than 2 & $6(12.0)$ \\
\hline
\end{tabular}

Table-1: (Continued)

\begin{tabular}{lc}
\hline Parameter & $\mathbf{n ~ ( \% )}$ \\
\hline Prefer not to say & $1(2.0)$ \\
Level of training attended & $42(84.0)$ \\
Basic & $3(6.0)$ \\
Advanced & $5(10.0)$ \\
Prefer not to say & \\
Place of trainings & $24(48.0)$ \\
Ubay, Bohol & $31(62.0)$ \\
VSU & $2(4.0)$ \\
University of the Philippines/Central Luzon & \\
State University & $4(8.0)$ \\
Others & \\
Last AI training attended & $9(18.0)$ \\
Within 1 year & $6(12.0)$ \\
2 years ago & $32(64.0)$ \\
3 years ago or more & $3(6.0)$ \\
Prefer not to say
\end{tabular}

AIT=Artificial insemination technician, LGU=Local government units, VSU=Visayas State University

(44\%). The preferred time of insemination was morning (44\%). Insemination was done 3 times by $74 \%$ of AITs. Almost all (96\%) AITs confirmed pregnancy at 3 months after AI (64\%). Estrus synchronization was also done by most AITs (86\%). All of them educate the farmers on these different profiles (Table-2).

\section{AI success rates}

The operation year 2011 had the highest recorded success rate (Table-3). High number of trainings were reportedly conducted during this year (personal communication), which might have an influence on the performance. The lowest observed success rate was in 2015, which may be due to lack of an updated reported data on calf drops. A high success rate (64.4\%) was observed in Biliran in 2012 but may be misleading due to the low number of recorded AIs performed (45 inseminations only) during the year. A decrease in the success rates after 2011 was observed, for most locations in 2013. The decrease in success rates may have been caused by Super Typhoon Haiyan, which caused major damage to Eastern Visayas. A slight increase in success rates can be observed in the year 2014, indicating recovery from the aftermath of the typhoon. However, the computed success rates were found lower than the national performance $(40 \%)$ [15].

\section{Statistical analyses}

A significant difference was found between AI success and civil status of AITs for most years except 2012 (Table-4). This study showed that married technicians had higher success rates than single or widowed AITs. While further study may be needed to clarify the role of civil status in AI performance, married technicians may be more patient and with better interpersonal skills, which were found associated with good inseminators [10]. A significant correlation was also found between the average number of AI per year and AI success. Technicians having an average of more than 100 AIs had higher success rates than 
Table-2: AI practices employed by technicians in Eastern Visayas $(n=50)$.

\begin{tabular}{|c|c|}
\hline Parameter & n (\%) \\
\hline \multicolumn{2}{|l|}{ Checking of heat prior to AI } \\
\hline Yes & $50(100)$ \\
\hline No & $0(0)$ \\
\hline \multicolumn{2}{|l|}{ Method of checking heat } \\
\hline Vulval swelling & $30(60)$ \\
\hline Soft cervix & $9(18)$ \\
\hline Rectal palpation & $32(64)$ \\
\hline Reddish coloring of vagina & $32(64)$ \\
\hline Clear mucus discharge & $46(92)$ \\
\hline Others & $2(4)$ \\
\hline \multicolumn{2}{|l|}{ Pre-AI information gathered } \\
\hline Time of discharge & $23(46)$ \\
\hline Time of heat & $45(90)$ \\
\hline Amount of discharge & $12(24)$ \\
\hline Species of water buffalo & $8(16)$ \\
\hline \multicolumn{2}{|c|}{$\begin{array}{l}\text { Time (hours) of response after gathering } \\
\text { information }\end{array}$} \\
\hline $1-12$ & $35(70)$ \\
\hline $13-24$ & $2(4)$ \\
\hline Above 24 & $3(6)$ \\
\hline \multicolumn{2}{|c|}{ Method of checking thawing temperature } \\
\hline Not at all & $2(4)$ \\
\hline Thermometer & $42(84)$ \\
\hline Hand & $9(18)$ \\
\hline \multicolumn{2}{|l|}{ Checking of thawing time } \\
\hline No & $0(0)$ \\
\hline Yes & $50(100)$ \\
\hline \multicolumn{2}{|c|}{ Method of checking thawing time } \\
\hline Watch & $11(22)$ \\
\hline Manual/mental counting & $38(76)$ \\
\hline Others & $1(2)$ \\
\hline \multicolumn{2}{|c|}{ Thawing time practiced (seconds) } \\
\hline $1-10$ & $28(56)$ \\
\hline $11-20$ & $14(28)$ \\
\hline 21 and above 30 & $4(8)$ \\
\hline \multicolumn{2}{|l|}{ Instrument used to cut straw } \\
\hline Cutter & $27(54)$ \\
\hline Scissors & $29(58)$ \\
\hline \multicolumn{2}{|c|}{ AI straw orientation during cutting } \\
\hline Angled & $12(24)$ \\
\hline Straight & $38(76)$ \\
\hline \multicolumn{2}{|c|}{ Use of plastic gloves during rectal palpation } \\
\hline No & $1(2)$ \\
\hline Yes & $49(98)$ \\
\hline \multicolumn{2}{|l|}{ Reusing of gloves } \\
\hline No & $26(52)$ \\
\hline Yes & $24(48)$ \\
\hline \multicolumn{2}{|l|}{ Use of lubricant } \\
\hline No & $8(16)$ \\
\hline Yes & $41(82)$ \\
\hline \multicolumn{2}{|l|}{ Lubricant used } \\
\hline Soap & $33(66)$ \\
\hline Manure & $25(50)$ \\
\hline KY Jelly & $1(2)$ \\
\hline Others & $1(2)$ \\
\hline \multicolumn{2}{|l|}{ Site of usual semen deposition } \\
\hline Mid-cervix & $9(18)$ \\
\hline Entrance & $4(8)$ \\
\hline Body of uterus & $43(86)$ \\
\hline Deposition after ideal time e & \\
\hline Mid-cervix & $22(44)$ \\
\hline Entrance & $17(34)$ \\
\hline Body of uterus & $12(24)$ \\
\hline Vaginal canal & $0(0)$ \\
\hline Usual time of insemination & \\
\hline Morning & $22(44)$ \\
\hline
\end{tabular}

Table-2: (Continued)

\begin{tabular}{lc}
\hline Parameter & $\mathbf{n}(\%)$ \\
\hline Afternoon & $9(18)$ \\
Both times & $19(38)$ \\
Frequency of insemination & \\
Once & $1(2)$ \\
Twice & $8(16)$ \\
Thrice & $37(74)$ \\
Confirmation of pregnancy & \\
No & $2(4)$ \\
Yes & $48(96)$ \\
Performance of pregnancy diagnosis & \\
post-AI (months) & \\
1 & $2(4)$ \\
2 & $4(8)$ \\
3 & $32(64)$ \\
4 & $6(12)$ \\
5 or more & $2(4)$ \\
Estrus synchronization & \\
No & $0(0)$ \\
Sometimes & $43(86)$ \\
Always & $4(8)$ \\
Education of farmers & \\
No & $0(0)$ \\
Yes & $50(100)$ \\
\hline AI=Artificial insemination &
\end{tabular}

Table-3: AI success rates (\%) of selected areas in Eastern Visayas, Philippines (2011-15).

\begin{tabular}{lccccc}
\hline Location & $\mathbf{2 0 1 1}$ & $\mathbf{2 0 1 2}$ & $\mathbf{2 0 1 3}$ & $\mathbf{2 0 1 4}$ & $\mathbf{2 0 1 5}$ \\
\hline Leyte & 11.4 & 8.8 & 8.1 & 9.9 & 3.0 \\
Southern Leyte & 17.4 & 4.7 & 8.9 & 9.7 & 0.9 \\
Biliran & 13.5 & 64.4 & - & 7.1 & 1.1 \\
Western Samar & 10.8 & - & 10.9 & 10.3 & 1.8 \\
Northern Samar & 6.2 & 6.3 & 1.7 & 1.0 & - \\
\hline
\end{tabular}

$\mathrm{AI}=$ Artificial insemination

those who had below 100 inseminations per year. This is contrary to the findings of Cembrowics [16] where the number of inseminations did not affect the success of AI. However, a high number of inseminations can be associated with better familiarity of the reproductive system [11] and higher confidence of the technician [17] leading to higher success rates.

The study also found a significant association between the number of trainings attended and AI success rate. However, this could be considered a confounder because all AITs were required to attend at least one training before practicing AI. Studies have shown that participation in refresher courses can lead to higher AI success rates $[13,14,17,18]$. Moreover, statistical significance was found between training in PCC Ubay and AI success rate. Results showed that AITs who attended training in PCC Ubay have lower success rates than those who attended training in VSU or in Luzon. Since training of AITs has been shown to be very vital in maintaining a satisfactory breeding efficiency [17], further studies are needed to evaluate this observation because training in PCC Ubay is longer in duration than those conducted in PCC at VSU.

For the AI practices employed, the analysis revealed that checking of heat through evaluation of 
Table-4: Results of statistical analyses with significant results ( $p$ value).

\begin{tabular}{|c|c|c|c|c|c|}
\hline \multirow[t]{2}{*}{ Parameter } & \multicolumn{5}{|c|}{ Year } \\
\hline & 2011 & 2012 & 2013 & 2014 & 2015 \\
\hline \multicolumn{6}{|l|}{ Profile } \\
\hline Civil status & $0.050 *$ & 0.922 & $0.047 *$ & $0.034 *$ & $0.039 *$ \\
\hline Average AI per year & 0.085 & 0.217 & 0.766 & 0.858 & $0.008 * *$ \\
\hline Number of trainings attended & $0.025 *$ & 0.389 & $0.047 *$ & 0.072 & 0.161 \\
\hline Training at PCC Ubay & $0.007 * *$ & 0.783 & $0.000 * *$ & $0.010 * *$ & $0.000 * *$ \\
\hline \multicolumn{6}{|l|}{ Practice/practice } \\
\hline Checking heat by soft cervix & 0.056 & 0.399 & 0.208 & $0.009 * *$ & 0.253 \\
\hline Checking heat by rectal palpation & 0.613 & 0.41 & $0.008 * *$ & $0.004 * *$ & 0.504 \\
\hline Checking heat by reddish coloring of vagina & $0.014 *$ & 0.492 & 0.752 & 0.767 & 0.292 \\
\hline Checking heat by the amount of vaginal discharge & $0.046 *$ & 0.353 & 0.115 & $0.012 *$ & 0.713 \\
\hline Checking of thawing time using watch & 0.174 & 0.234 & 0.517 & 0.483 & $0.018^{*}$ \\
\hline Cutting AI straw using cutter & $0.017 *$ & 0.258 & 0.15 & 0.107 & $0.013^{*}$ \\
\hline Cutting AI straw with an angled orientation & 0.377 & 0.48 & 0.225 & $0.009 * *$ & 0.283 \\
\hline Semen deposition at the entrance of the cervix & 0.154 & 0.81 & 0.247 & 0.462 & $0.000 * * *$ \\
\hline Semen deposition at the uterine body & $0.019 *$ & 0.73 & 0.63 & 0.265 & 0.523 \\
\hline Deposition at mid-cervix after standard time elapsed & 0.399 & 0.145 & $0.035 *$ & 0.059 & 0.884 \\
\hline Deposition at entrance after standard time elapsed & $0.033 *$ & 0.243 & 0.286 & 0.614 & $0.013 *$ \\
\hline Deposition at uterine body after standard time elapsed & 0.222 & 0.726 & 0.26 & $0.004 * *$ & $0.005 * *$ \\
\hline
\end{tabular}

*Significant, $* * / * * *$ Highly significant. AI=Artificial insemination

soft cervix, reddish coloring of vagina, amount of discharge and by rectal palpation, and checking of thawing time using watch were significant. Checking and monitoring of heat and thawing time have been shown to be vital to the health and breeding efficiency of animals [19-21]. On the other hand, cutting the AI straw using a cutter with an angle orientation was also found statistically significant. Duponte [22] explained that cutting the straw straight across prevents back flushing of semen into the insemination gun. Moreover, semen deposition at the entrance of the cervix, uterine body, and at mid-cervix, and at the entrance of cervix and uterine body after standard time elapsed were also found significant. Semen deposition site is shown to influence calves' sex [23], but another study noted that semen deposition sites have no effect and that sperm concentration appeared to be more significant in the success of conception [24].

\section{Conclusion}

Technician profile factors, including civil status, average AI per year, the number of trainings attended, and training may have an influence on the success of AI. For the practices, checking of soft cervix, rectal palpation, reddish coloring of vagina, amount of discharge, thawing temperature check by hand, thawing time check by watch, cutting straw by cutter and at an angle, semen deposition at entrance, semen deposition at uterus body, and deposition at mid-cervix may also influence the success of AI. From 2011 to 2015, AI success rates in Leyte, Samar, and Biliran were below the $40 \%$ national performance. The AITs, farmers, and LGU must exert more effort to improving AI performance. Although technician's profile and practices can be critical to the success of AI, other factors including social and logistics may also be significant. It is recommended that AITs should attempt to perform more AIs per year. Moreover, a nationwide study may be conducted to assess and evaluate the profile, practices, and performance of AITs to improve national AI performance rate.

\section{Authors' Contributions}

APY and RHDY contributed equally to the study. APY and RHDY conceptualized the study, and analyzed and wrote the manuscript. MOC, LVM, JVA, ESN, ESN, JTR and IFML contributed in the data collection and giving valuable inputs to the manuscript. All authors have read and approved the final manuscript.

\section{Acknowledgments}

The authors would like to thank the veterinarians and staff of the PCC at VSU, Baybay City, and Leyte for their assistance.

\section{Competing Interests}

The authors declare that they have no competing interests.

\section{References}

1. Khalifa, T., Rekkas, C., Samartzi, F., Lymberopoulos, A., Kousenidis, K. and Dovenski, T. (2014) Highlights on artificial insemination (AI) technology in the pigs. Maced. Vet. Rev., 37: 5-34.

2. Lima, F.S., de Vries, A., Risco, C.A., Santos, J.E.P. and Thatcher, W.W. (2010) Economic comparison of natural service and timed artificial insemination breeding programs in dairy cattle. J. Dairy Sci., 93: 4404-4413.

3. Rehmana, F.U., Zhaoa, C., Shaha, M.A., Qureshib, M.S. and Wanga, X. (2013) Semen extenders and artificial insemination in ruminants. Veterinaria, $1: 1-8$.

4. Inchaisri, C., Jorritsma, R., Vernooij, J.C.M., Vos, P.L.A., Van der Weijden, G.C. and Hogeveen, H. (2011) Cow effects and estimation of success of first and following inseminations in Dutch dairy cows. Reprod. Domest. Anim., 46: 1043-1049

5. Duran, P., Corpuz, H.K., Gaspar, D.C., Misola, C.M., Munar, M. and Hufana-Duran, D. (2015) Non-invasive 
clinical diagnosis of estrus for AI synchronization using vaginal cytology in three bubaline breeds in the Philippines. Res. J. Pharm. Biol. Chem. Sci., 6: 562-567.

6. Cruz, L.C. (2010) Recent developments in the buffalo industry of Asia. Rev. Vet., 21(1): 7.

7. Duran, D. and Duran, P. (2015) Advanced reproductive technologies in water buffalo. In: Purohit, G.N., editor. Bubaline Theriogeneology. International Veterinary Information Service, Ithaca, NY.

8. Chaikhun, T., Hengtrakunsin, R., De Rensis, F., Techakumphu, M. and Suadsong, S. (2012) Reproductive and dairy performances of Thai swamp buffaloes under intensive farm management. Thai. J. Vet. Med., 42: 81.

9. Perry, G.A., Dalton, J.C. and Geary, T.W. (2010) Management factors influencing fertility in synchronized and natural breeding programs. Proceedings, Applied Reproductive Strategies in Beef Cattle January 28-29, 2010; San Antonio, TX.

10. Russi, L., Costa-e-Silva, L., Zuccari, C. and Recalde, C. (2010) Human resources in artificial insemination of beef cattle: Profile of managers and inseminators. Rev. Bras. Zootec., 39: 7. http://dx.doi.org/10.1590/ S1516-35982010000700010.

11. Singh, J. and Nanda, A. (2007) Interventions for improving the fertility of crossbred cows subjected to artificial insemination under field conditions. Improving the Reproductive Management of Dairy Cattle Subjected to Artificial Insemination. IAEA, Vienna, Austria.

12. Everett, R. and Bean, B. (1986) Semen fertility - An evaluation system for artificial insemination sires, technicians, herds, and systemic fixed effects. J. Dairy Sci., 69: 1630-1641.

13. Akhtar, T., Lodhi, L., Khanum, S., Rashad, M. and Hussain, M. (2007) Improving reproductive efficiency in an artificial insemination programme through early non-pregnancy diagnosis, management and training. Improving the Reproductive Management of Dairy Cattle Subjected to Artificial Insemination. IAEA, Vienna, Austria.

14. Boettcher, P. and Perera, B. (2007) Improving the reproductive management of smallholder dairy cattle and the effectiveness of artificial insemination: As summary. Improving the Reproductive Management of Dairy Cattle Subjected to
Artificial Insemination. IAEA, Vienna, Austria.

15. Roque, A. (2011) People Find Their Calling in Artificial Insemination. Available from: https://business.inquirer. net/482/people-find-their-calling-in-artificial-insemination accessed on 25-05-2016.

16. Cembrowics, H. (1964) Efficiency of inseminators. In: Proceeding $5^{\text {th }}$ International Congress Animal Reproduction Artificial Insemination. Vol. 4. p624-630.

17. Santolaria, P., Lopez-Gatius, F., Sanchez-Nadal, J.A. and Yaniz, J. (2012) Relationships between body weight and milk yield during the early postpartum period and bull and technician and the reproductive performance of high producing dairy cows. J. Reprod. Dev., 58: 366-370.

18. Berry, D.P., Evans, R.D. and Mc Parland, S. (2011) Evaluation of bull fertility in dairy and beef cattle using cow field data. Theriogenology, 75: 172-181.

19. Aungier, S.P.M., Roche, J.F., Sheehy, M. and Crowe, M.A. (2012) Effects of management and health on the use of activity monitoring for estrus detection in dairy cows. $J$. Dairy Sci., 95: 2452-2466.

20. Roca, J., Parrilla, I., Rodriguez-Martinez, H., Gil, M.A., Cuello, C., Vazquez, J.M. and Martinez, E.A. (2011) Approaches towards efficient use of boar semen in the pig industry. Reprod. Domest. Anim., 46: 79-83.

21. Oliviera, L.Z., Arruda, R.P., de Andrade, A.F.C., Santos, R.M., Beletti, M.E., Peres, R.F.G., Martins, J.P.N. and Hossepian de Lima, V.F.M. (2012) Effect of sequence of insemination after simultaneous thawing of multiple semen straws on conception rate to timed AI in suckled multiparous Nelore cows. Theriogenology, 78: 1800-1813.

22. DuPonte, M. (2007) Proper Semen Handling During an Artificial Insemination Program. Cooperative Extension Service, College of Tropical Agriculture and Human Resources, University of Hawai' $i$ at Mānoa.

23. Zobel, R., Gereš, D., Pipal, I., Buić, V., Gračner, D. and Tkalcic, S. (2011) Influence of the semen deposition site on the calves sex ratio in simmental dairy cattle. Reprod. Domest. Anim., 46: 595-601.

24. Foote, R.H. (2013) Physiological aspects of artificial insemination. In: Cole, H.H. and Cupps, P.T., editors. Reproduction in Domestic Animals. $2^{\text {nd }}$ ed. Academic Press, United States of America. p313-315. 